\title{
Chapter 9 \\ Persistence or Change: Divergent Trajectories of Large Housing Estates in Budapest, Hungary
}

\author{
Zoltán Kovács, Tamás Egedy and Balázs Szabó
}

\begin{abstract}
In post-socialist cities of Central and Eastern Europe, large housing estates became dominant features of post-war housing development. Unlike in Western Europe, these neighbourhoods were not developed for immigrants and the poorest segment of society. Instead, they provided homes for lower middle class and working class families with stable incomes. After the change of regime, however, these neighbourhoods experienced different development trajectories not only on the international but also on national and city levels. With regard to contemporary developments of housing estates, Budapest provides a typical post-socialist case where housing estates are continuously re-evaluated by the people and the market, while socialist legacies leave their imprints on the actual socio-economic developments. This chapter focuses on the development of large housing estates in Budapest and in Hungary before and after the transition. Today, one-fifth of the Hungarian population and one-third of Budapest's residents live in housing estate neighbourhoods. The main objectives of the study are to display the spatial distribution of different generations of housing estates at the national and city level with special emphasis on their physical and social characteristics. The chapter also sheds light on the consequences of the post-socialist transition on the recent developments of housing estates in Budapest. After almost three decades of transition, debates about housing estates and their future possibilities are still relevant in Hungary and Budapest, because some of these neighbourhoods are experiencing a renaissance in the housing market, attracting younger and better off strata, whereas others show symptoms of socio-economic decline.
\end{abstract}

Z. Kovács $(\varangle)$

Department of Human Geography, University of Szeged, Szeged, Hungary

e-mail: zkovacs@iif.hu

Z. Kovács · T. Egedy · B. Szabó

Hungarian Academy of Sciences, Budapest, Hungary

e-mail: egedy@gmx.net

B. Szabó

e-mail: szbazs@gmail.com

(C) The Author(s) 2018

D. B. Hess et al. (eds.), Housing Estates in Europe, The Urban Book Series,

https://doi.org/10.1007/978-3-319-92813-5_9 
Keywords Housing estates - Post-war housing development • Housing policy Urban regeneration - Budapest, Hungary

\subsection{Introduction}

Similar to other post-socialist cities of Central and Eastern Europe, housing estates became dominant features of the urban structure in Budapest after World War II (Sýkora 2009). Providing shelter for about one-third of the city's population, housing estates represent a significant part of the local housing stock and they satisfy the needs of a great variety of socio-economic groups, but mainly the less affluent segments of society. After the demise of state-socialism, liberalisation of the housing market as well as changing residential preferences of people created new opportunities for housing markets. Dwellings located in housing estates became re-evaluated and they generally tended to lose their previous prestige (Kovács and Herfert 2012). The global financial crisis and the subsequent shrinkage on the demand side of the housing market further exacerbated the downward process. However, housing estates are not at all homogeneous. We can identify substantial differences among them, according to age, size, building technology, accessibility and the quality of the built environment (Kovács and Douglas 2004).

The main aim of this chapter is to shed light on the main socio-economic changes of large housing estates that have taken place in Budapest since the change of regime. Our analysis builds on data from three previous censuses (1990, 2001 and 2011) and relevant media and policy documents referring to recent developments of large housing estates. The main research questions are as follows: How has the post-socialist transformation affected the housing estates of Budapest and whether the socialist heritage still persists or not? To what extent is physical and social decline typical for housing estates? How have the different generations of housing estates been affected by decline or upgrading? Focusing on these questions, we outline the overall development trends of housing estates in Budapest and discuss the socio-economic, structural and environmental challenges that have affected them in the last three decades. We also try to conceptualise our findings and place them in the wider context of urban development in Budapest dominated by urban sprawl (i.e. suburbanisation) and most recently urban regeneration (i.e. gentrification).

\subsection{The Evolution of Housing Estates in Hungary with Special Attention to Budapest}

In Hungary, the first housing-estate-like neighbourhoods appeared before World War I. These early estates were garden-city type compounds with primarily small dwellings built for the working class. They were built by state companies (e.g. 


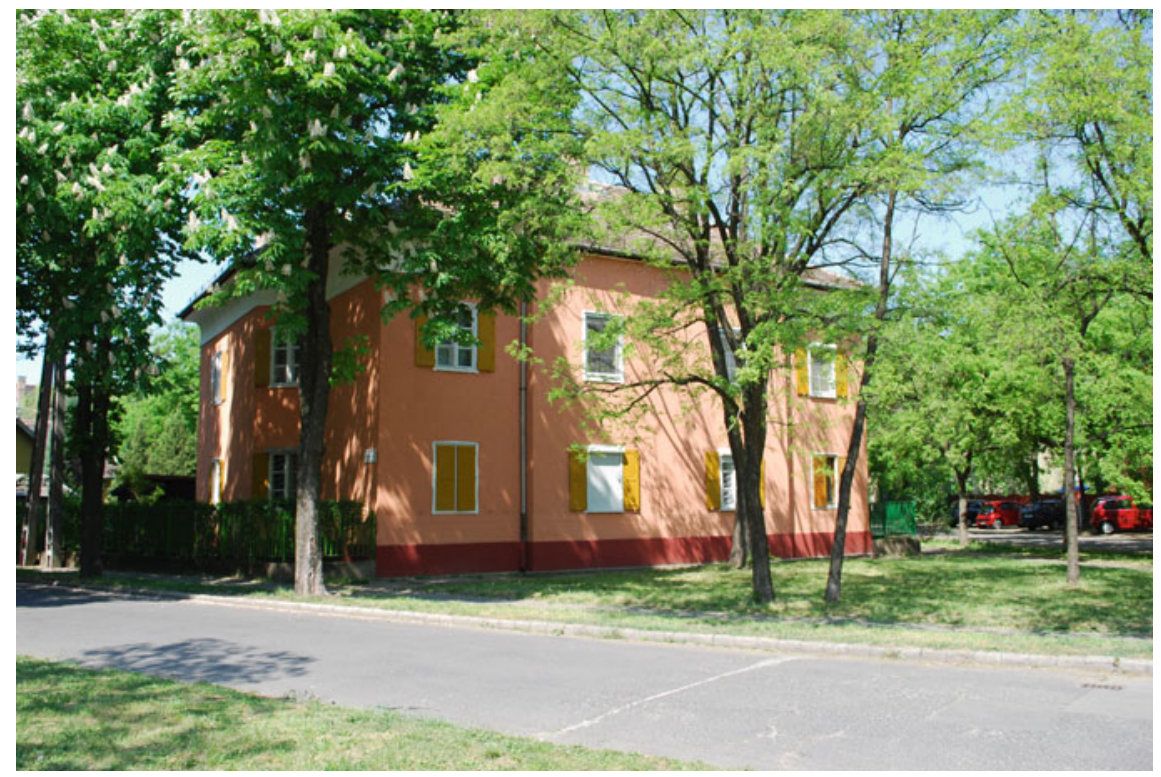

Fig. 9.1 Wekerle garden city, built at the beginning of the 20th century at the then urban fringe of Budapest. Source Kovács, Egedy and Szabó

national railway) or large municipalities like Budapest, which, for instance, erected the Wekerle-estate at the fringe of the city after 1908 (Fig. 9.1).

In the interwar period, housing shortages and overcrowding of dwellings became serious challenges in Budapest. In the 1920s, several low-quality barrack estates were built in order to ease the housing shortage and provide shelter for Hungarian refugees expelled from territories acquired by Romania, Yugoslavia and Czechoslovakia. By 1932, there were 18 barrack estates in Budapest containing nearly 6,400 homes and housing about 40,000 people, mainly in low-quality one-room flats without running water and sanitation (Gyáni 1992; Györi 1996). Housing estates meeting modern criteria appeared in Hungary only after World War II. The first project was launched in 1948 and it was the continuation of a smaller scale housing estate (Fiastyúk utca) planned and partly constructed before WWII. The general notion of housing estates applied in Hungary followed very much the concept of Clarence Perry's neighbourhood scheme, though without size limits. Housing estates had to form coherent neighbourhoods with strict internal organisation, separated from the surrounding neighbourhoods by arterial streets with distinct names. Taking into account their construction period, size, physical layout and the building materials used, we can define four generations of housing estates in Hungary and Budapest. 


\subsubsection{Housing Estates of the 1950s}

In the late 1940s and early 1950s, there were few housing estates built in Hungary since the communist regime designated the majority of state revenues for post-war reconstruction and forced industrialisation, including the development of socialist new towns (e.g. Dunaújváros, Várpalota, Komló, Kazincbarcika). At the same time, housing received low priority in the economic plans of the late 1940s and 1950s; thus, housing construction fell below the level of the interwar period and the population grew faster than the housing stock. These conditions raised serious tensions within Hungarian society. In urban areas, especially in Budapest and other major cities, the mismatch between supply and demand in the housing market was even more severe due to high immigration from rural areas. In 1949, the estimated national housing shortage was around 265,000 dwellings (and 63,000 dwellings or $23.7 \%$ in Budapest) (Sillince 1985). Public money spent on housing construction started to rise significantly after 1953 when the orthodox communist leader of the country, Mátyás Rákosi, was replaced by Imre Nagy. By the end of the decade, the proportion of dwellings built in housing estates in Budapest rose from the previous 20 to $40 \%$ (Preisich 1998).

Housing estates in the 1950s were most often developed on sites close to the inner-city, which had already been provided with public utilities or were easily accessible. These housing estates could be characterised by their 'human scale' physical form and a relatively small size comprising between 300 and 800 dwellings. Buildings were made of bricks arranged in a frame structure surrounding courtyards and squares. The height of houses did not exceed 3-4 levels. These estates became tangible symbols of the new system and the architectural style (sometimes popularly referred to as 'Stalin baroque') left distinct traces on the cityscape (Fig. 9.2).

Housing estates built in the 1950s undoubtedly improved the quality of urban life. Although the share of one-room apartments was extremely high (52\%), the comfort level of the apartments was significantly better than average as most of the dwellings were equipped with running water, bathroom and toilet (Fóti 1988). Residents of housing estates of the 1950s could be characterised by a strong working class profile and were loyalists to the communist system.

\subsubsection{Housing Estates of the 1960s}

In the 1960s, the principles of modernist architecture spread all over Hungary and standardisation in housing construction became commonplace. The construction of large housing estates at the urban edge was adopted as a major strategy for urban growth. Thanks to the block construction technology, apartment buildings in housing estates started to 'rise'. In addition to the 3- to 4-storey buildings typical of the 1950s, 9- to 10-storey blocks appeared in the second half of the decade. It was 


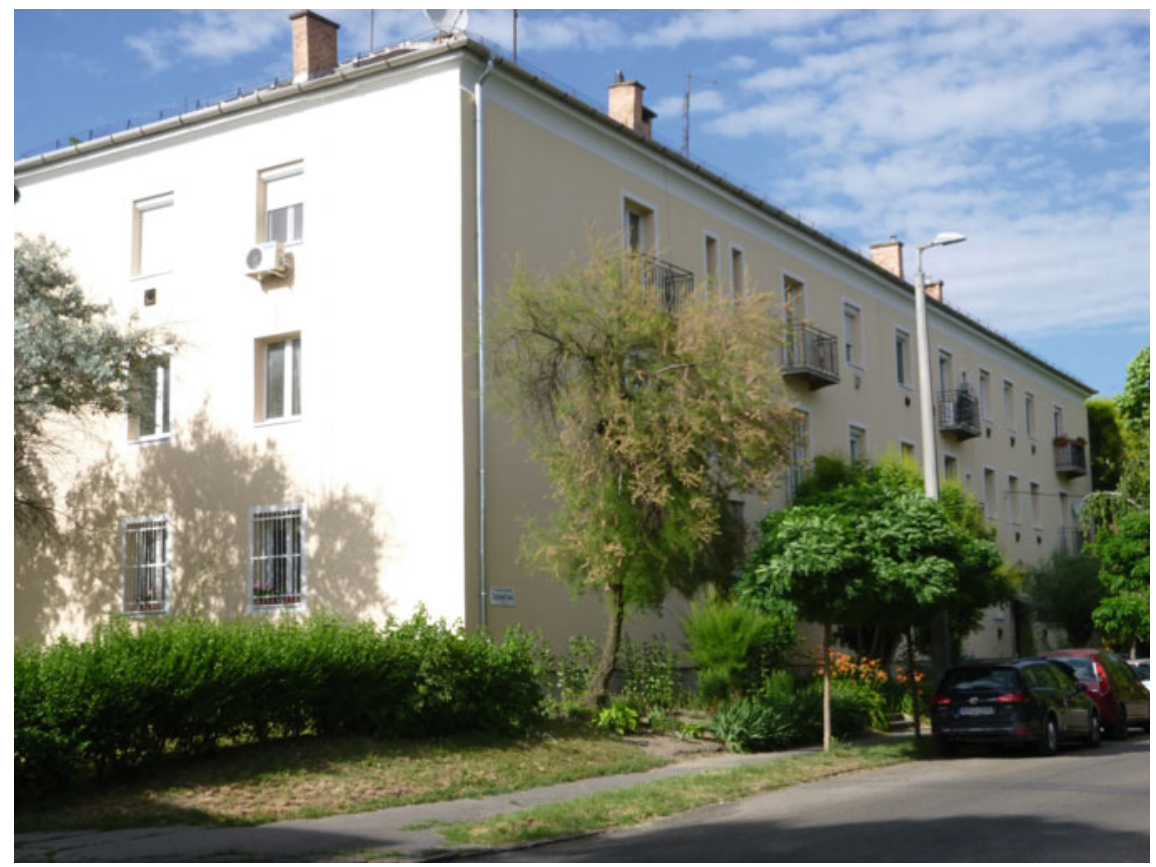

Fig. 9.2 Gubacsi housing estate in the 20th district of Budapest, built in the 1950s. Source Kovács, Egedy and Szabó

no surprise that the first pioneering reports on the sociological problems of large housing estates were published in the late 1960s (Szelényi and Konrád 1969) though without much resonance.

State housing policy changed in 1960, when the so-called ' 15 -year housing development programme' was launched in Hungary, which aimed at building one million new dwellings in Hungary (with a population of 10 million), out of which 250 thousand was foreseen for Budapest. The succeeding years saw a rapid increase in state housing expenditure and construction. Eventually, the plan was fulfilled, primarily thanks to a substantial overshot in private construction. Within the framework of the programme, a total of 187,000 apartments were built in Budapest, of which about 106,000 were built in the 1960s (Preisich 1998). However, the overall housing situation did not improve since the number of households grew faster than the number of dwellings.

In the 1950s, the share of public and private sectors in new housing construction was more or less balanced, but in the 1960s, $68 \%$ of new dwellings in Budapest were built by the state. Compared to the previous decade, the composition of dwellings was more favourable since the share of two-room apartments with bathroom and central heating considerably increased. At the same time, the average size of housing estates also increased, requiring more urban space. Consequently, the majority of housing estates in the 1960 s were built further from the city centre in 
the so-called transition zone, and housing estate construction gradually shifted towards the periphery (Pieniążek 2010).

Throughout the 1960s, block construction was gradually replaced by point and line houses, inner courtyards disappeared and large amounts of undeveloped space dominated the layout (Fig. 9.3). The average size of housing estates also increased to 1,000-2,000 dwellings. The prestige of these housing estates was considerably higher than the existing housing stock, thus, they became very much favoured by young middle-class families with children who often moved away from the outdated inner-city dwellings to new housing estates (Csanádi and Ladányi 1992; Szelényi and Konrád 1969).

By the mid-1960s, it became obvious that the ambitious objectives of the 15-year housing development programme could not be fulfilled by conventional construction technologies. Therefore, the decision was made to adopt the technology of the Soviet housing factories (the first were produced in Budapest in 1965). Housing factories made housing construction faster and more economical and permitted buildings of various sizes and heights (Benkő 2015).

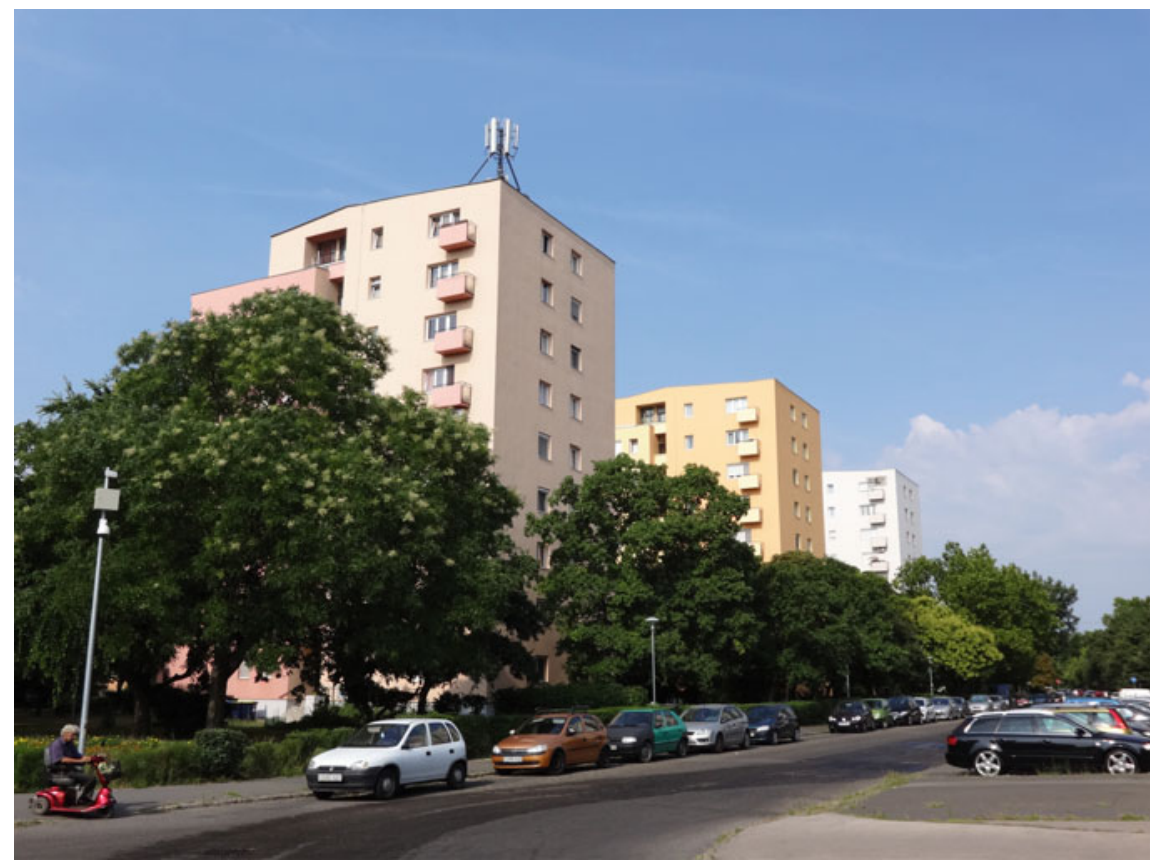

Fig. 9.3 József Attila housing estate, built in the 9th district of Budapest using mixed building technology in the 1960s. Source Kovács, Egedy and Szabó 


\subsubsection{Housing Estates of the 1970s}

The 1970s marked the peak of housing construction in Hungary during state-socialism, due to the proliferation of pre-fabricated technology. By 1976, 10 housing factories and 6 panel plants were in operation, producing 35,000 dwellings per year in the country. With this technology, a large number of dwellings could be built quickly and at reasonable cost, mainly in the form of large housing estates. It became an important aspect of the state-socialist welfare system that the urban population could expect sooner or later to obtain access to public dwelling if they wished. This never applied to the rural population, however, which was expected to solve its housing problems through private and 'self-help' channels.

Housing estate development concentrated mainly in Budapest and other larger regional centres (e.g. Miskolc, Debrecen, Szeged, Pécs). In Budapest, the number of newly constructed dwellings reached its apex in 1975 with close to 20,000 new units (Fig. 9.4). More than $70 \%$ of the new dwellings were built by the state with pre-fabricated panel technology. Huge housing estates were established, often in 5-year-run periods, with 5000-15,000 flats housing 30,000-40,000 people.

The layout and architectural character of the 1970s housing estates was increasingly determined by the Soviet type large-panel technology. Ten-storey high strip houses became dominant, mostly with five (and sometimes 10) staircases (Iván 1996). A permanent tension arose between architects and the representatives of the state investors, as cost considerations influenced all aspects of planning. There was very little opportunity for variation in the building composition, the interior

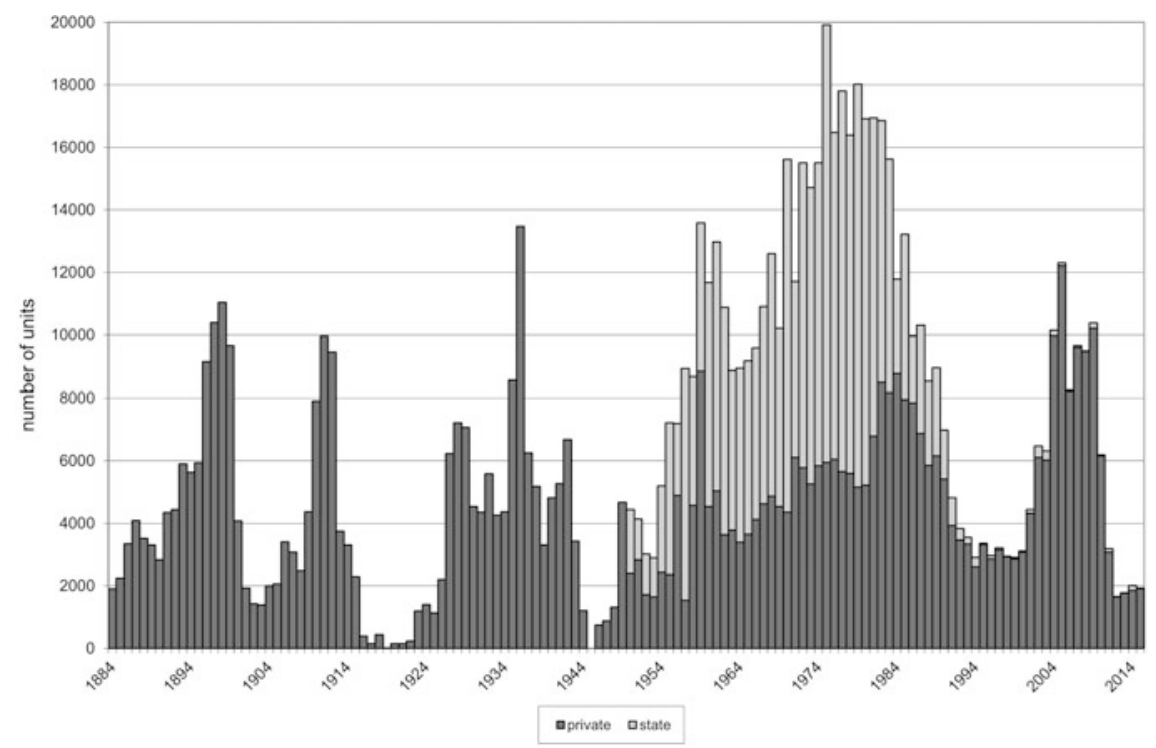

Fig. 9.4 New dwellings constructed in Budapest, 1884-2015 


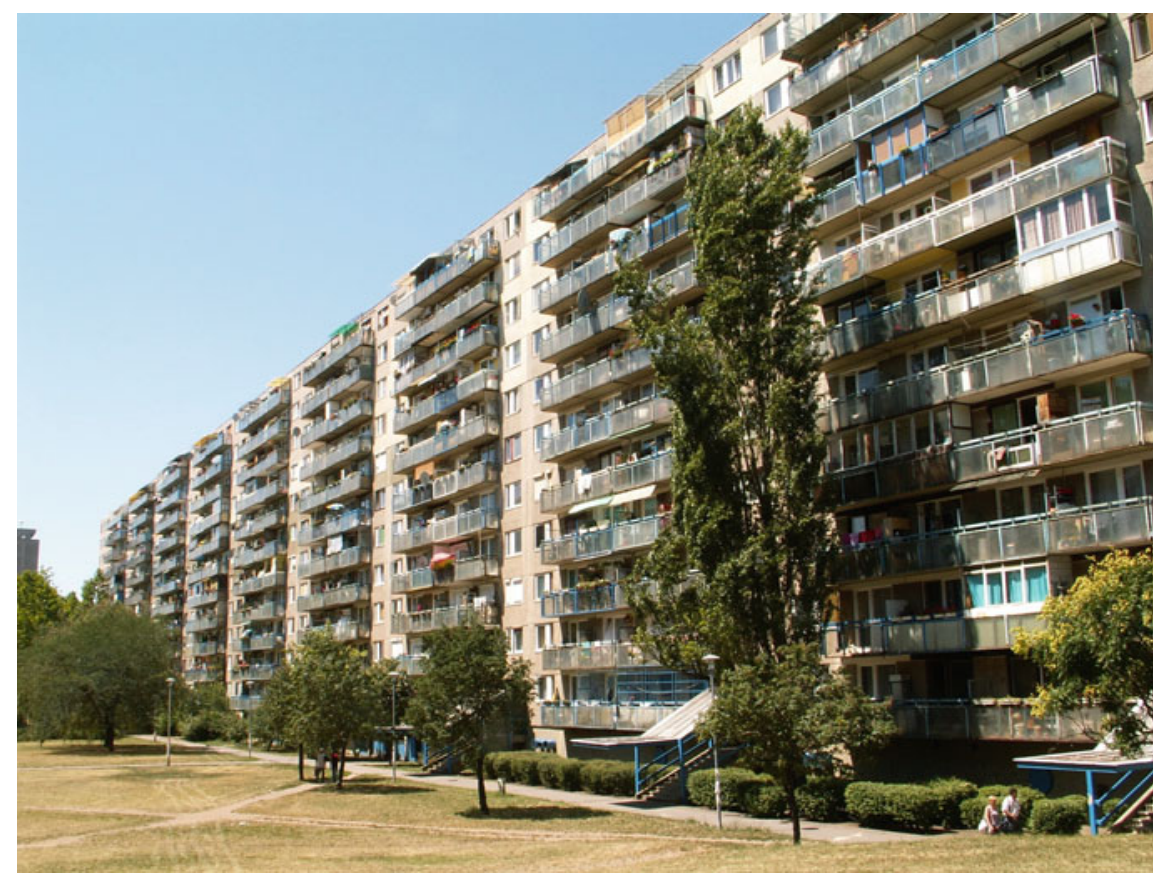

Fig. 9.5 Havanna housing estate in the 18th district of Budapest, built using pre-fab technology in the late 1970s. Source Kovács, Egedy and Szabó

organisation of flats, and other details. Reducing costs alone was possible with the abandonment of the construction of public institutions, which became one of the most serious deficiencies in these housing estates. The large pre-fabricated housing estates ensured housing quantity, but the quality of living conditions for the population at large became an enduring topic of discussion (Hall et al. 2005; Benkő 2015). Simultaneously, new housing estates increasingly shifted to the periphery of the city, where excessive un-urbanised areas offered cheap construction opportunities (Fig. 9.5).

Compared to the previous decade, the share of one-room flats significantly decreased in housing estates, while the proportion of two- and three-room apartments increased. The level of comfort also rose; central and district heating became widespread and full comfort remained, for a long time thereafter, the most important quality feature of these apartments. The 1970s also brought about changes in the social composition of housing estates. The Housing Act of 1971 made the state-led delivery of dwellings dependent on income level and social conditions, primarily on the number of children. Thus, poorer and less educated people could have better access to public housing, and the average social status of new housing estates decreased accordingly (Rietdorf et al. 1994; Farkas and Szabó 1995; Rietdorf 1997). 


\subsubsection{Housing Estates of the 1980s}

Economic difficulties in the late 1970s drove the government to revise and modify its welfare policy, which soon meant vigorous changes in housing policy too. New measures, introduced in 1983, effectively set out to abolish the previous extensive subsidies for housing. The number of dwellings built by the state gradually decreased and the dominant form of new housing became privately owned single-family homes.

In the 1980s, thanks to efforts to 'humanise' the environment of housing estates, planners managed to break through the schematism characterising the estates in the previous decades. Housing factories gradually produced more varied types of buildings. Lower buildings of 4- to 5-storeys appeared again in housing estates, and tentatively even 1- to 2-storey row houses were built. The size of housing estates rarely exceeded 2,000-3,000 dwellings. The quality requirements for panel technology also changed. As new technological standards came into being, the efficiency of thermal insulation had to be increased. In the 1980s, the construction spread of more attractive panel buildings with pitched roof (Fig. 9.6).

The share of dwellings built by the contribution of private capital steadily grew, either as cooperative housing or as condominiums with the support of OTP (state bank of Hungary before the change of regime). This had positive effects on the

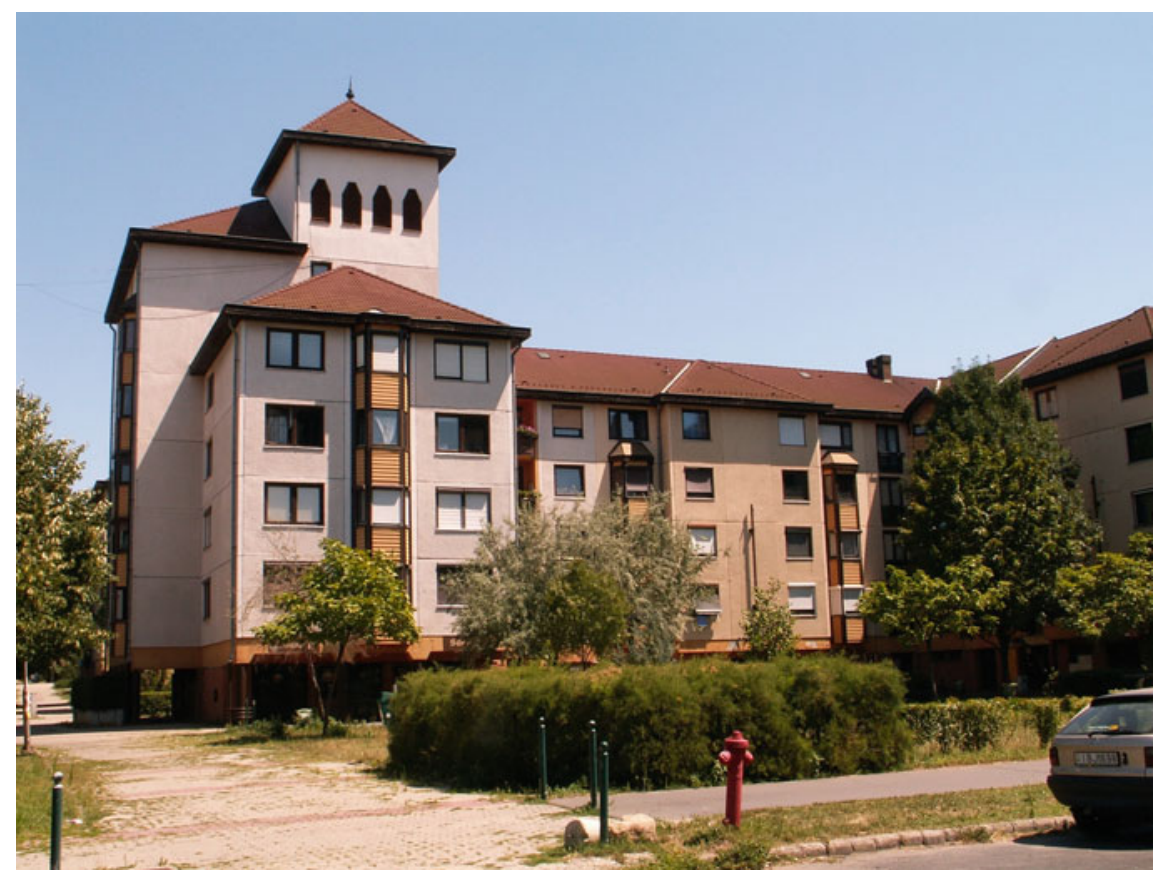

Fig. 9.6 Gloriette housing estate built in the late 1980s in the 18th district of Budapest. Source Kovács, Egedy and Szabó 
composition of dwellings: the size of flats generally increased and their internal division became more varied. As a consequence, these housing estates were much more popular than their counterparts from the 1970s; their prestige clearly exceeded those built in the previous decade.

In the early 1990s, the construction of housing estates ceased in Hungary and a new era of development began in the housing market with the mushrooming of residential parks and other upmarket residential compounds (Kovács and Hegedüs 2014). These homogeneous residential enclaves are perceived by some scholars as the newest generation of housing estates, symbolising the advent of global capitalism and its dominant lifestyle (Csizmady and Csanádi 2009).

We can conclude that housing construction between 1950 and 1990 was characterised by the increasing predominance of housing estates. Especially in the 1970s, the proportion of dwellings built in housing estates was extremely high. Towards the end of the period, the construction of housing estates gradually declined and abruptly ceased. While housing estates of the 1950s still embodied considerable social expectations, their prestige declined in the following decades and only the elite housing estates in the late 1980s restored a positive image.

\subsection{Housing Estates in Hungary and Budapest}

\subsubsection{Distribution of Housing Estates at the National Level}

Official statistics about housing estates were first published by the Hungarian Central Statistical Office after the 1980 census. At that time, $15.2 \%$ of the Hungarian housing stock was located in housing estates. The definition of housing estates applied was: 'a group of mid-rise and high-rise blocks and rows of houses built mostly by pre-fabricated technology in the last decades.' Since the construction of new dwellings in housing estates ceased by the early 1990s, the micro-census carried out by the Central Statistical Office in 1996 provides compelling information about their overall significance. In 1996, approximately 786,000 (or 20\%) of the Hungarian housing stock was situated in housing estates (Table 9.1).

The average size of housing estates in Hungary is relatively small compared to other East Central European (especially post-Soviet) countries, and $71 \%$ of Hungarian housing estates have fewer than 1,000 dwellings. Giant housing estates, having more than 10,000 apartments, are very rare; only 9 such giant estates were recorded and only two of them are located outside Budapest (in Miskolc and Pécs).

Figure 9.7 shows the spatial distribution of larger housing estates with over 1,000 dwellings in Hungary. There were 173 such estates in 1996, and the overwhelming majority of them were located in: (i) Budapest, (ii) the county seats and (iii) the so-called 'socialist new-towns' (Dunaújváros, Ajka, Komló, Ózd etc.). The geographic distribution of housing estates in Fig. 9.7 is uneven in Hungary; cities of the more industrialised northern and western regions are well supplied with this 
Table 9.1 Size distribution of housing estates in Hungary. Source HCSO Micro-census 1996 and author-conducted survey

\begin{tabular}{l|l|l|r|r|r}
\hline $\begin{array}{l}\text { Size (number of } \\
\text { dwellings) }\end{array}$ & $\begin{array}{l}\text { Number of } \\
\text { housing estates }\end{array}$ & $\begin{array}{l}\text { Total number of } \\
\text { dwellings }\end{array}$ & $\begin{array}{l}\text { Ratio } \\
(\%)\end{array}$ & $\begin{array}{l}\text { Total } \\
\text { population }\end{array}$ & $\begin{array}{l}\text { Ratio } \\
(\%)\end{array}$ \\
\hline $10.000<$ & 9 & 121,900 & 15.5 & 342,900 & 15.2 \\
\hline $7.500-10.000$ & 7 & 61,400 & 7.8 & 164,300 & 7.3 \\
\hline $5.000-7.500$ & 21 & 131,800 & 16.8 & 388,800 & 17.2 \\
\hline $2.500-5.000$ & 41 & 137,900 & 17.6 & 375,900 & 16.6 \\
\hline $1.000-2.500$ & 95 & 149,100 & 19.0 & 440,600 & 19.4 \\
\hline $1.000>$ & $\sim 430^{\mathrm{a}}$ & 183,400 & 23.3 & $549,700^{\mathrm{a}}$ & 24.3 \\
\hline Total & $\sim 600^{\mathrm{a}}$ & 785,500 & 100.0 & $2,262,100^{\mathrm{a}}$ & 100.0 \\
\hline
\end{tabular}

${ }^{\mathrm{a} E s t i m a t e s}$

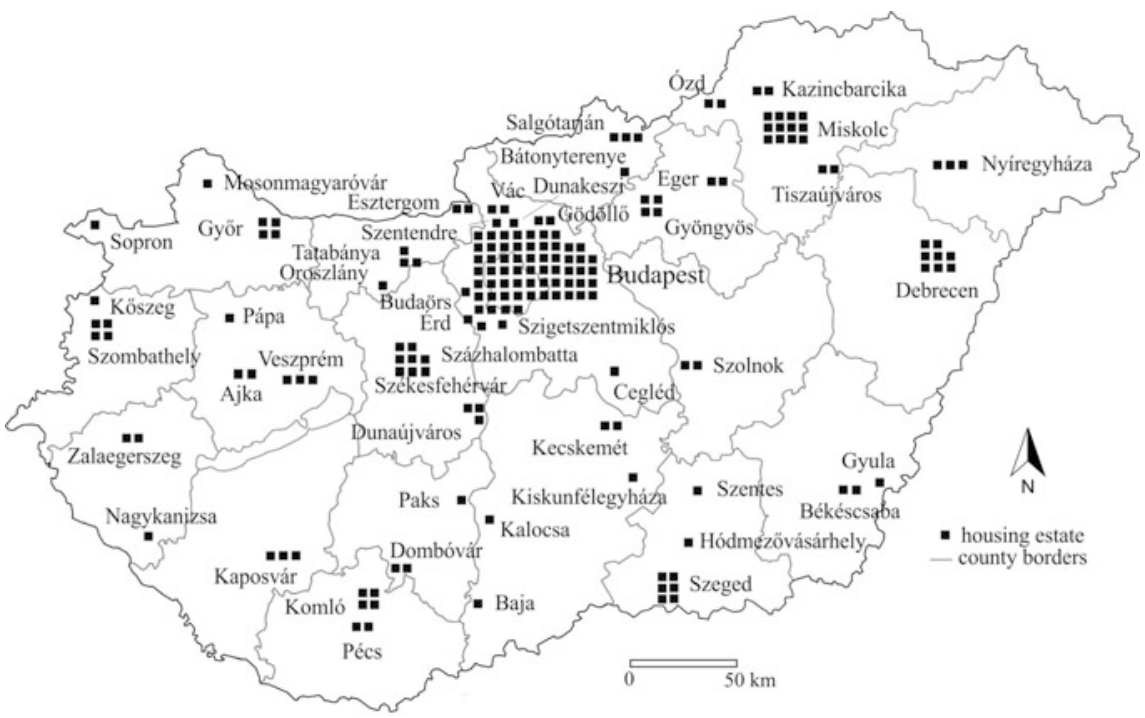

Fig. 9.7 Spatial distribution of large housing estates (1,000 or more dwellings), 1996, Hungary. Source HCSO Micro-census 1996 and author-conducted survey

form of housing, whereas in the predominantly agricultural south-eastern regions, only the major administrative centres (e.g. Szeged, Debrecen) have large housing estates.

Hungarian housing estates are dominated by two-room flats with $50-59 \mathrm{~m}^{2}$ (44\%), while apartments larger than $80 \mathrm{~m}^{2}$ are rare (1.8\%). A trend emerges: the younger the housing estate, the larger the average floor space. The average level of comfort of the housing estates has always been higher than the rest of the housing stock. This has been the main factor that attracted younger and better educated people to housing estates in the state-socialist period. However, housing estates 
built in the 1970s and 1980s with central heating became very costly by the 1990 s due to dramatic energy price increases. Not surprisingly, younger and more mobile residents departed housing estates and moved to the suburbs in the first years of the transition (Kovács and Tosics 2014).

\subsubsection{Characteristics of Housing Estates in Budapest}

In Budapest, there are 121 officially recognised housing estates (Micro-census 1996). For the sake of the present study, we identify a housing estate as group of 1,000 or more dwellings in mid-rise or high-rise buildings, developed as a coherent and compact planning unit. Altogether 62 estates, ca. half of the 121 officially recognised housing estates, meet these criteria. According to the 2011 national census, there were 239,750 dwellings located in these housing estates in Budapest, i.e. $30.5 \%$ of the total housing stock, providing home for $29.5 \%$ of the population.

In terms of the time of construction, $63.1 \%$ of the dwellings in housing estates were constructed in the 1970s. This is the most dominant group of housing estates with uniform style buildings erected by pre-fabricated systems. Housing estates of the 1980 s comprise $16.2 \%$, while housing estates of the 1960 s encompass $13.6 \%$ of the housing stock. The smallest group is made up of small-scale housing estates built in the $1950 \mathrm{~s}$, where only $7.1 \%$ of the housing estates dwellings are concentrated. This categorisation of age will reappear later in our analysis on the trajectories of the various generations of housing estates in Budapest (Fig. 9.8).

In terms of size, housing estate dwellings are generally below the city's average. While the share of smaller dwellings (i.e. below $40 \mathrm{~m}^{2}$ ) is about the same (ca. 17\%) as in other parts of Budapest, larger apartments are nearly completely missing. Apartments above $80 \mathrm{~m}^{2}$ comprise only $1.6 \%$ of the dwelling stock in housing estates while it is $28 \%$ in the rest of the city. As opposed to size parameters, the level of comfort is very favourable in housing estates. $89 \%$ of flats have full comfort (central heating and full sanitation) while in the rest of the city, only $64 \%$ of dwellings fall into this category.

As far as tenure is concerned, in $20114.1 \%$ of the dwellings in housing estates were owned by local governments (i.e. district governments) and used as public rentals. This figure is below the city's average (5.1\%). In 1990, the share of public rental dwellings in housing estates was higher (48.4\%), but due to large-scale privatisation programmes, their number radically decreased. After 1990, in the transformation of the housing market, privatisation of public dwellings played an important role. Privatisation of state housing in Budapest meant a pure 'give away' type of privatisation to sitting tenants, at remarkable low prices (Hegedüs 2013). The 1993 Housing Law made privatisation of public housing compulsory with the 


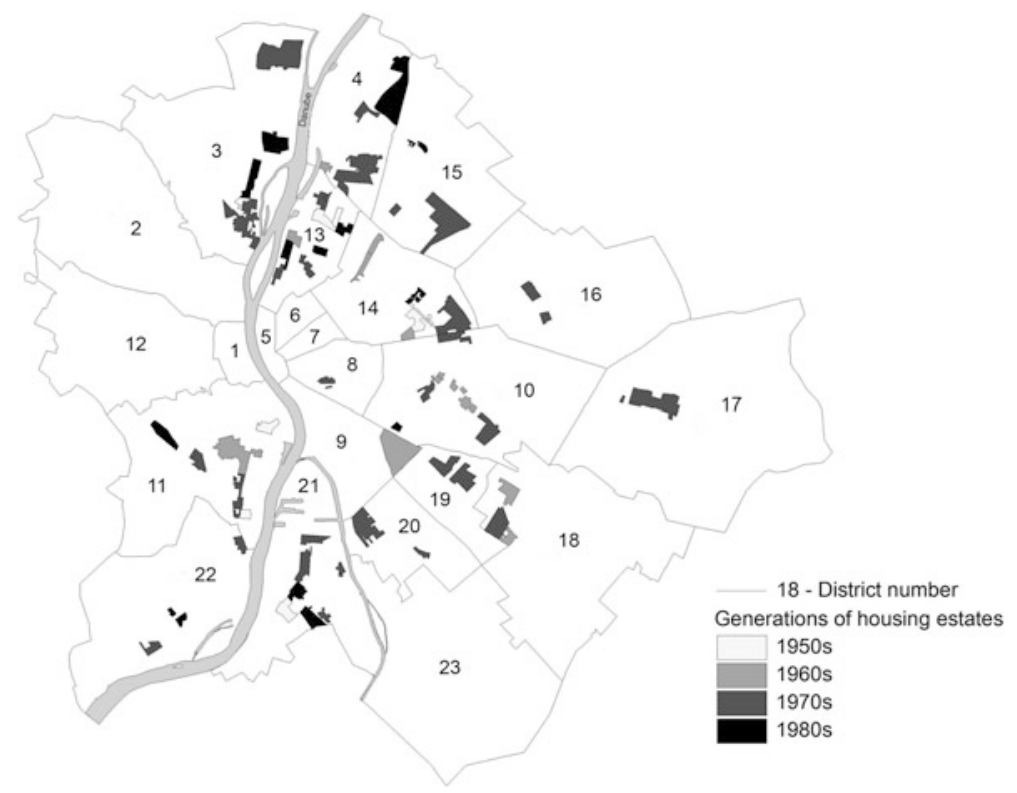

Fig. 9.8 Spatial distribution of four generations of large housing estates (1,000 or more dwellings), 2011, Budapest. Source HCSO Census 2011

introduction of the Right to Buy. As a consequence, the share of public housing in Budapest decreased from $51 \%$ to a mere $5.1 \%$ by 2011 .

Regarding the age structure of residents, housing estates have a fairly similar profile to the city's average, however, younger age groups (below age 20) are slightly underrepresented, and older cohorts (above age 60) are slightly over-represented. Differences in the demographic profile of residents are more pronounced among the various generations of housing estates. In terms of educational attainment, residents of housing estates are generally less educated, the share of those having a university diploma in the adult (20+) population was $24.1 \%$ in 2011, whereas it was $36.2 \%$ in the rest of the city.

The spatial distribution of housing estates is very much determined by the physical geography of the city. East of the Danube, on the plain Pest side of Budapest, there are favourable opportunities for housing estate construction, while on the hilly Buda side, only limited areas near the river could accommodate housing estates. Consequently, the share of housing estates within the housing stock is somewhat higher on the Pest side (32\%), than on the Buda side (27\%). In terms of the socio-economic status of residents, it is also important to emphasise that housing estates located on the environmentally more attractive Buda side have always had higher prestige. 


\subsection{Socio-economic Changes in Housing Estates in Budapest After 1990}

In this section, we focus on the position of housing estates in the housing market, with special emphasis on how the demographic and socio-economic profile of housing estates changed after 1990. Our findings are based on comparative analysis of data from the three most recent censuses (1990, 2001 and 2011). We also provide an overview of how the different generations of housing estates developed during the post-socialist transition.

The share of population living in large housing estates has decreased in Budapest since 1990 (Table 9.2). On the eve of the political changes, 33.9\% of the city's population lived in housing estates, which decreased to $29.5 \%$ by 2011 . After 1990 , Budapest experienced substantial population loss due to suburbanisation and natural decline, however, the loss in housing estates was more in relative terms than in the rest of the city.

In terms of the demographic structure of the population, like other post-socialist cities, Budapest has been strongly affected by ageing. This is also true for housing estates, but the pace of ageing in housing estates was faster than the city's average. In 1990, the share of younger age groups (i.e. below 20) was much higher, and the proportion of older age groups (above 60 years) was significantly lower in housing estates than elsewhere (Fig. 9.9). These differences practically disappeared by 2011, and even the share of older generations (above 40 years) became somewhat higher in housing estates than in Budapest.

Demographic change and most notably ageing affected the various generations of housing estates differently. Census data suggest that the generations of the 1970s and 1980s are most affected by ageing, whereas the share of elderly (above 60 years) decreased in the 1950 s estates from 35.1 to $29.7 \%$ between 1990 and 2011. Although previous research from the 1990s determines a linear correlation between the age of housing estate and ageing of the local population (Egedy 2000; Csizmady 2003), this trend seems to have changed since the turn of the millennium. We suggest a reason for this change: the mobility of people. Even though housing estates have below average mobility rates, $30.5 \%$ of the residents had moved to the

Table 9.2 Share of housing estates in Budapest, 1990-2011. Source HCSO Census 1990, 2001, 2011

\begin{tabular}{l|l|l|l|l|r|l}
\hline & 1990 & 2000 & \multicolumn{2}{l}{2011} & \multicolumn{1}{l}{} \\
\cline { 2 - 7 } & $\mathrm{N}$ & $\%$ & $\mathrm{~N}$ & $\%$ & $\mathrm{~N}$ & $\%$ \\
\hline Number of people & 683,556 & 33.89 & 580,046 & 32.73 & 509,461 & 29.49 \\
\hline Number of dwellings & 250,199 & 31.51 & 240,347 & 32.69 & 239,718 & 30.45 \\
\hline Public rental dwellings & 121,171 & 30.61 & 12,400 & 19.50 & 9,831 & 24.40 \\
\hline ISCO7-8-9 & 122,658 & 36.69 & 66,239 & 37.98 & 57,256 & 35.62 \\
\hline Unemployed & 25,427 & 30.93 & 17,105 & 34.57 & 28,077 & 31.26 \\
\hline Large households (5-) & 16,011 & 38.86 & 10,589 & 28.57 & 7,119 & 23.36 \\
\hline
\end{tabular}




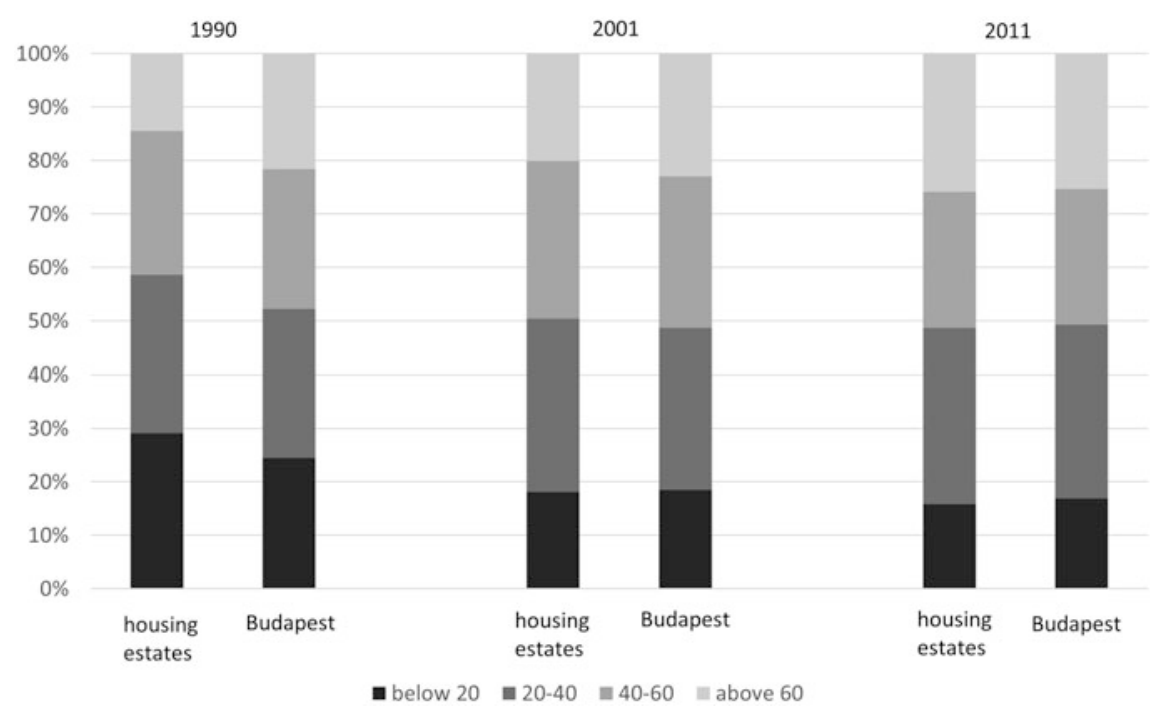

Fig. 9.9 Demographic structure of population, 1990-2011. Source HCSO Census 1990, 2001, 2011

present dwelling before 1990 , whereas it is only $22.8 \%$ for the rest of the city. Residential mobility induced robust population change. The most remarkable population change took place in the housing estates of the 1950s where the proportion of newcomers significantly increased after 1990. This finding is also confirmed by changes in household structure. The share of single-person households grew in each generation of housing estates after 1990, however, higher growth rates were clearly evident in the housing estates of the 1950s and 1960s. A decreasing share of elderly and a growing share of single-person households suggest the arrival of younger, single people to the oldest generations of housing estates and a possible socio-economic upgrading.

To measure the socio-economic status of local residents and the level of segregation, we use data for education and occupation. But beforehand, we must note two important features which make the situation of housing estates in Budapest different from Western cities. First, as opposed to the West, housing estates in Hungary were not constructed for the lowest socio-economic strata (as in social housing programmes). In fact, the exact opposite is true: in the 1960s and early 1970s, housing estates had a clear middle-class profile (Szelényi and Konrád 1969). Second, Hungary (and other post-socialist countries) was not affected by large-scale immigration from former colonies or other less developed countries after World War II. Thus, ethnically and culturally, Hungarian society remained fairly homogeneous. Indicators for ethnicity used in other (predominantly Western) cities are inappropriate in measuring segregation in Budapest. Census data indicate a growing gap between housing estates and the rest of Budapest as far as educational attainment is concerned (Fig. 9.10). 


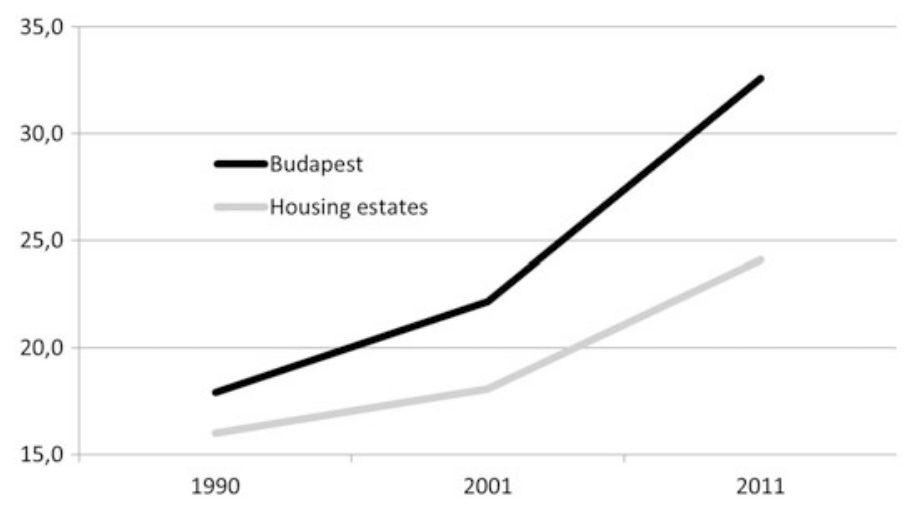

Fig. 9.10 Share of residents with a university or college degree, 1990-2011. Source HCSO Census 1990, 2001, 2011

Figure 9.10 depicts that the share (in 1990) of those with a university or college degree among people 20 years or older was fairly similar in housing estates and in the rest of Budapest; by 2011, however, a gap arose. On the eve of the last census, $32.6 \%$ of Budapest residents (older than 20 years) had earned a degree, but it was only $24.1 \%$ in the housing estates. Thus, the global trend of professionalisation of the labour force was slower in housing estates than in the city. Different generations of housing estates followed very different pathways. In 1990, the share of graduates was the lowest in the housing estates built in the 1950s. However, by 2011, the situation in these housing estates had improved considerably due to population change, and the proportion of people with the highest qualifications nearly reached the level of the 1980s generation, which otherwise was very much favoured by young intellectuals in the time of construction. On the other hand, the share of graduates is lowest in housing estates dating from the 1970s, and the gap compared to other generations has clearly grown since 1990 .

To detect changes in the socio-economic status of housing estates and the level of social segregation, we use occupational data for the economically active population, according to the occupational categories of ISCO (International Standard Classification of Occupations). In order to simplify the analysis, we aggregated the top two (managers, professionals) and bottom three (industrial workers, machine operators, unskilled workers) categories, and refer to them hereinafter as 'intellectuals' and 'workers'.

The general trends are clear: in 1990, the share of intellectuals was somewhat lower and the share of workers was slightly higher in housing estates than the city's average. The professionalisation of the labour force progressed in housing estates resulting in higher shares of intellectuals and lower shares of workers, however the pace of changes was less dynamic than in the rest of the city. As a consequence, occupational differences between housing estates and the rest of the city increased, and the working class character of housing estates strengthened. In 2011, the share of workers was $24.6 \%$ in housing estates, whereas only $19.2 \%$ in the rest of the city. 
Among the different generations of housing estates, the share of workers was highest in the housing estates of the 1970s. Housing estates of the 1950s managed to change their working class profile after 1990, since the proportion of intellectuals increased more rapidly than in other generations. Consequently, the prestige of these housing estates has continuously grown.

We conclude that housing estates in Budapest have been affected considerably by ageing and lowering socio-economic status in relative terms since 1990 . Nevertheless, different generations of housing estates followed very different trajectories. Housing estates of the 1950s had a disadvantageous position in 1990 with ageing population, and a less educated, predominantly lower class population. However, after the change of regime, these housing estates were considerably re-evaluated by the city's inhabitants; they attracted younger and better educated residents and their prestige started to grow. As a consequence, the working class profile of these estates gradually changed and their population became demographically more balanced. Housing estates of the 1960s started the post-socialist transition from a better position than the 1950s generation, and their prestige and social status was generally higher. Since the turn of the millennium, this generation has been characterised by similar trends in social transformation like the 1950s, and these two older generations seem to be attractive options on the housing market. The biggest losers of the transformation were housing estates of the 1970s, built by pre-fabricated technology. These estates have been hit by a downward spiral where younger, more educated people gradually moved out; at the same time, the elderly, lower class profile of these estates strengthened. However, this group is not homogeneous either: the largest, more monotonous housing estates built in working class neighbourhoods with poor image are in the worst position. Housing estates of the 1980s were in the most favourable position in 1990 as far as their prestige and social composition were concerned. They were highly appreciated by younger, middle-class families, and consequently, their status was higher compared to other generations. However, between 1990 and 2011, social transformation processes were not as favourable as previously (Kovács and Douglas 2004). Higher social status of this generation is still detectable, but its favourable position is diminishing.

\subsection{Post-socialist Transition and the Challenges of Large Housing Estates}

During the post-socialist transition, various phases of development could be distinguished in housing estates. In the first period (early 1990s), the most important factor affecting the development of housing estates was privatisation (Sailer-Fliege 1997; Hegedüs 2013). By the late 1990s, only 5-6\% of the housing stock in housing estates remained in the hands of local governments. Increasing private home ownership paved the way for market-led property development and residential mobility. A high level of comfort was one of the main advantages of 
pre-fabricated housing estates before 1990. That very same feature became the main disadvantage after 1990, due to rapidly rising housing costs, especially energy costs (Egedy 2000). After privatisation, the new owners living in pre-fabricated housing estates had to face a difficult situation: the relative value of apartments in pre-fabricated buildings declined while running costs drastically increased. As a consequence, lower status residents in housing estates often became trapped: they could not sell their flats or buy another one of similar quality; thus, their housing career ended (Hegedüs and Tosics 1998). Rapidly rising housing costs were connected with inefficient central heating systems and the insufficient insulation of houses, therefore, rehabilitation interventions were needed urgently.

The second development period started with the rehabilitation of housing estates in 1997. In 1996, the Ministry of Economy, the Hungarian Development Bank and the German Creditanstalt für Wiederaufbau created a 30-million deutsche mark (ca. 3 billion HUF at the current exchange rate) credit facility in order to support energy saving renewal (Government Decree 105/1996). It was the first important intervention in the history of pre-fabricated buildings organised by the state. Under the scheme, $75 \%$ of the renovation costs in panel buildings could be financed by the credit construction. The loan programme was extended several times until 2001, yet only about one-third (950 million HUF) of the budget was drawn, because of the strict conditions. Also in 1997, the Energy Saving Loan Program was launched, whereby municipalities could get a loan totalling of 800 million HUF. The programme continued with an additional one billion HUF credit facility in 1998. These early regeneration programmes paved the way for a large-scale, nationwide intervention called 'Panel Programme' where the European Union took a lion's share.

The Panel Programme, signalling the third development phase of housing estates, was launched in 2001. The EU-funded renovation programme targeted the improvement of energy efficiency in pre-fabricated buildings. It has been renamed and restructured several times since its start, but it is still the most prominent and largest state-financed residential rehabilitation programme in Hungary (Panel I, 2001-2008; Panel II, 2009-2013; Panel III, 2014-2020). Unfortunately, it is extremely difficult to obtain accurate and tangible data on the number of renewed apartments and the amount of public subsidies used in the programme, as there are different numbers in government (national and local) and other professional documents. According to the latest data, a total of 320,000 pre-fabricated dwellings have been renovated in Hungary in the Panel Programme between 2000 and 2014. Within the framework of Panel Program III, which has been underway since 2014, a total of 380,000 flats are planned to be included in the energy efficiency renovation (lasting until 2020), or 75\% of the total housing stock.

In 2017, the development of large pre-fabricated housing estates once again rose high on the agenda of national politics in Hungary. In 2017, the government began to elaborate a new 20- to 25-year panel regeneration strategy aimed at improving the quality of life of people living in panel housing estates by improving the residential environment. The programme is currently in the preparatory phase, but it is certain that the government will not rule out the partial demolition of pre-fabricated buildings either. 
Concerning demolition, it is important to know the opinion of local residents living in large housing estates. In 2014, a questionnaire survey was carried out in Budapest with the aim to measure the satisfaction of residents living in downgrading neighbourhoods. The survey covered four neighbourhoods including Hungary's second largest housing estate, Újpalota (15th District of Budapest), erected using pre-fabricated technology in the early 1970s. Other neighbourhoods were selected in the densely built inner-part and the low-rise outer fringe of the city. Respondents were randomly surveyed from renovated and non-renovated buildings of housing estates. Survey data show that local residents of housing estates have more negative opinion about their neighbourhood than people living in other run-down quarters (Table 9.3).

The negative internal image highly correlates with residential mobility chances. Almost one-third of the residents in Ujpalota feel that they are stuck in the housing estate (unable to move due to financial or other reasons), while this share is less than one-fifth in other downgrading areas. The renewal process started in the quarter only in the late 2000s and remained limited until now. However, the very few respondents living in renovated houses already expressed their higher satisfaction with the neighbourhood compared to those living in non-renovated buildings.

Although satisfaction with housing estates as a form of living varies greatly by country, city and neighbourhoods, the physical rehabilitation of pre-fabricated buildings (e.g. better insulation, lower level of noise, lower costs of heating, aesthetic aspects) improves the satisfaction of inhabitants (Kovács and Herpai 2011). Yet, the need for regeneration shows significant differences among the various types and generations of housing estates, and often within the same generation. For instance, regarding the pre-fabricated panel buildings, there is a much higher demand for renewal in housing estates of the 1970s showing infrastructural and architectural problems than those of the 1980s, but there are also significant differences between housing estates built in the first and the second half of the 1980s (van Kempen et al. 2005). In the first half of this decade, mainly large, 'traditional' housing estates were built, while during the second half, smaller scale elite housing estates became dominant. In the latter group, there is less need for full renovation.

Table 9.3 Perception of declining neighbourhoods by residents in Budapest, 2014

\begin{tabular}{l|l|l|l}
\hline Statement & \multicolumn{3}{|l}{$\begin{array}{l}\text { Percentage of those residents who totally or } \\
\text { partly agree with the statement }\end{array}$} \\
\cline { 2 - 4 } & $\begin{array}{l}\text { Újpalota, } \\
\text { non-renovated } \\
\text { buildings }\end{array}$ & $\begin{array}{l}\text { Újpalota, } \\
\text { renovated } \\
\text { buildings }\end{array}$ & $\begin{array}{l}\text { Other } \\
\text { declining areas } \\
\text { of Budapest }\end{array}$ \\
\hline $\begin{array}{l}\text { 'The value of dwellings is continuously } \\
\text { decreasing in this neighbourhood' }\end{array}$ & 92.4 & 81.3 & 66.1 \\
\hline $\begin{array}{l}\text { 'Mainly those people move into this } \\
\text { neighbourhood who cannot afford to buy a } \\
\text { flat somewhere else' }\end{array}$ & 83.0 & 45.5 & 37.7 \\
\hline
\end{tabular}


In this respect, other important factors - besides age and technology — are the size and location of housing estates. Generally, we can conclude that housing estates which are embedded in low-rise environments tend to be more commonly renovated. They are not elite housing estates, but typically smaller units (less than 1,000 dwellings) with low-rise buildings, and most of them differ little from their surroundings.

Another important factor about the perception of housing estates is the quality of environment and local services. Originally, great emphasis was placed on the proper provision of infrastructure and services in housing estates of the 1950s and 1960s; in the 1970s, however, due to a lack of financing and the acceleration of construction works, little attention was paid to this aspect. Thus, infrastructure and basic services were often lacking. After the change of regime, especially in the 1990s, small retail and service units (e.g. shops, pubs, hairdresser etc.) providing predominantly daily consumer goods and services appeared in the ground floor of panel buildings. With the renovation of housing estates and the construction of shopping centres at the urban fringe, and due to growing motorisation and the transformation of consumer culture, the role of these small service units has significantly diminished since the early 2000 s.

The evaluation of housing estate dwellings by the market has shown twists and turns since 1990. After the general relative decline of dwelling prices throughout the 1990s, there was growing appreciation on the market (after the turn of the millennium) accompanied by relative price increase. This was halted by the global financial crisis in 2008, followed by a frozen housing market with falling prices until 2013. Housing prices have rapidly risen in Budapest since 2014, and in recent years, housing estates became one of the most popular segments in the housing market. The reasons for growing popularity are manifold. Running costs of housing estate dwellings have not increased since 2013, and the average selling time of housing estate apartments is much shorter and prices are 20-30\% lower compared to apartments in brick buildings. Consequently, buyers of housing estate flats can enter the housing market more easily.

As far as the local self-governance of housing estates is concerned, we can conclude that housing estates are not the focus of political interest. There are only four districts in Budapest (out of the 23) that locally have a sub-municipality (a part of an upper tier municipal government), two of which are located in housing estates (4th district, Káposztásmegyer; 9th district, József Attila housing estate). This highlights a lack of self-governance and management in large housing estates. On the one hand, housing estates in Hungary and Budapest do not appear as independent administrative or urban planning entities, and they are therefore not targeted objects of municipal policies. The two aforementioned housing estates with partial local governments are not giant housing estates, suggesting the successful establishment of local sub-municipality cannot be linked with overall size (i.e. number of inhabitants). Rather, it is related to the local power relations and the activities of key persons and actors in the local community. After 2000, several attempts were made in other districts to establish sub-municipalities $(2008,11$ th district; 2009, 10th district), but these efforts failed; after 2010, due to the 
centralisation efforts of the conservative government, the issue of partial governance was removed from the agenda. Due to the lack of targeted policies for housing estates, there is no special attention given to housing estates in development tenders issued by the city or district governments. Thus, proposals are free to apply for housing estates and other residential areas (i.e. in general, there are no development tenders on local levels targeting exclusively at housing estates). For example, the Tér-Köz (Public-Space) programme in Budapest is aimed to draw attention to community building activities (e.g. innovative design of public areas, community programmes) and complex regeneration of public spaces. Although the call is not targeted specifically for housing estates, there is always a significant share of housing estate projects among the winners (for example, there were four housing estates subsidised in 2013 and 2016 by the programme).

Regarding the local civil society and civic life, the gradual strengthening of local communities and civic self-organisations could be witnessed in housing estates both in Budapest and the countryside. The process accelerated in two fundamental forms: first, local associations appeared in order to bring together active local residents (e.g. Association for the Centenarium Housing Estate in the 16th district founded in 2007, or Agora Local Patriot Association in the Lakatos Street housing estate in the 18th district founded in 2014) and, second, foundations have been established to finance local developments and institutions (e.g. Fund for the József Attila Housing Estate provided by the Ferencváros Community Association in the 9th district or Békásmegyer Church Foundation in the 3rd district).

\subsection{Conclusion}

Considering the number and size of its housing estates, Hungary has an intermediate position among European countries. The share of the population living in housing estates is approximately $20 \%$ in Hungary, and approximately $30 \%$ in Budapest. There are seven giant housing estates with more than 10,000 dwellings, but both Hungary and Budapest can be characterised by predominately small and medium-size housing estates. In 2011, the average size of housing estates (with more than 1,000 apartments) was 3,870 dwellings in Budapest, housing 8,200 people on average.

In Hungary, housing estates built after WWII can be readily categorised by the time of their construction. These housing estate generations show different features with regard to their physical layout and socio-economic characteristics. Socio-economic changes that took place after the change of regime (1989) are widely affected by the physical parameters of the housing and the dwelling stock (e.g. time and type of construction, age and size of housing estates).

Our results show that various generations of housing estates have followed distinct trajectories. In addition, their social composition remained relatively heterogeneous until now and became even more diversified due to the influx of new residents. 
Considering the composition of population by age and type of households, we can conclude that the technology applied (pre-fabricated systems or brick) strongly affected population changes that have taken place in the various generations. In older generations (especially in the housing estates of the 1950s), an influx of younger, better educated strata can be detected, while in younger generations (in housing estates of the 1970s and 1980) an ageing process and a relative socio-economic decline has taken place. Although the share of residents with tertiary education is growing in all housing estate generations, its dynamics lags behind the Budapest average; consequently, our results confirm, in relative terms, a gradual downgrading process in the social status of housing estates. The composition of population by occupation groups clearly demonstrates the social downgrading process of high-rise pre-fabricated housing estates built in the 1970s.

Housing estates in Hungary and Budapest generally provide home for lower middle class strata. Processes of social exclusion and an influx of immigrants (occurring in certain Western European housing estates) are not typical in Hungary or Budapest. Thus, problems regarding ethnicity, poverty, marginalisation and discrimination appear only in a very limited form compared to other European countries and cities.

Since housing estates do not appear as independent administrative or planning units, there are no targeted policies for housing estates per se either on the national or local level. However, the future of housing estates is permanently on the agenda in public debates. As a consequence of the long-term attention to the destiny of housing estates, the first attempts to improve the physical environment of housing estates date back to the late 1990s. Large-scale regeneration of pre-fabricated housing estates began in Hungary in 2001, and by the end of the 2010s, large share of pre-fabricated buildings will be modernised (with new insulation and heating systems). Rehabilitation seems to be an efficient instrument to prevent socio-economic decline and strengthen the position of large housing estates on the housing market. Despite the negative socio-economic tendencies, current market trends give rise to optimism about the future development of large housing estates. A large wave of urban sprawl terminated in Budapest by 2010, and since then the city has a moderate surplus of migration and population growth. The regeneration of inner-city neighbourhoods commenced since the turn of the new millennium, and the central city has been discovered again by younger and more affluent strata. In these dynamically changing housing market conditions, housing estates have a specific role to provide basic housing for newcomers (i.e. students), less affluent and elderly people. Sustainable demand is justified by housing market data and steadily growing dwelling prices since 2014 .

Acknowledgements Funding for the research leading to this publication was received from the Hungarian Scientific Research Fund (OTKA) Grant Agreement No. K119710. 


\section{References}

Benkő M (2015) The lifespan of large prefabricated housing estates in post-communist cities: an international comparison. Architektura \& Urbanizmus 49(3-4):180-197

Csanádi G, Ladányi J (1992) Budapest térbeni-társadalmi szerkezetének vál-tozásai. Akadémiai Kiadó, Budapest

Csizmady A (2003) A lakótelep. Gondolat Kiadó, Budapest

Csizmady A, Csanádi G (2009) From housing estates to gated communities. In: Smigiel C (ed) Gated and guarded housing in Eastern Europe. Forum Leibniz-Institut für Landerkunde, pp 9-20

Egedy T (2000) The situation of high-rise housing estates in Hungary. In: Kovács Z (ed) Hungary towards the 21st century, the human geography of transition. Geographical Research Institute, Hungarian Academy of Sciences, Budapest, pp 169-185

Farkas EJ, Szabó M (1995) Privatizáció és szociálislakás-gazdálkodás. Statisztikai szemle 73(12): 999-1014

Fóti P (1988) Röpirat a lakáshelyzetről Magvető Kiadó, Budapest

Gyáni G (1992) Bérkaszárnya és nyomortelep. Magvető Kiadó, Budapest

Győri P (1996) A várospolitika és a lakásépítés szerepe egyes szegregációs minták kialakulásában. In: Győri P (ed) A város, a város társadalma, életformacsoportok. Wesley János Lelkészképző Föiskola (szöveggyüjtemény), Budapest, pp 77-112

Hall S, Murie A, Knorr-Siedow T (2005) Large housing estates in their historical context. In: van Kempen R, Dekker K, Hall S, Tosics I (eds) Restructuring large housing estates in Europe. Policy Press, Bristol, pp 63-84

Hegedüs J (2013) Housing privatization and restitution in post-socialist countries. In: Hegedüs J, Lux G, Teller N (eds) Social housing in transition countries. Routledge, pp 33-49

Hegedüs J, Tosics I (1998) Towards new models of the housing system. In: Enyedi G (ed) Social change and urban restructuring in Central Europe. Akadémiai Kiadó, Budapest, pp 137-168

Iván L (1996) Mégegyszer a budapesti lakótelepekről. In: Dövényi Z (ed) Tér-GazdaságTársadalom-Huszonkét tanulmány Berényi Istvánnak. MTA Földrajztudományi Kutatóintézet, Budapest, pp 49-80

Kovács Z, Douglas M (2004) Hungary-from socialist ideology to market reality. In: Turkington R, van Kempen R, Wassenberg F (eds) High-rise housing in Europe: current trends and future prospects, housing and urban policy studies 28. University Press, Delft, pp 231-248

Kovács Z, Hegedüs G (2014) Gated communities as new forms of segregation in post-socialist Budapest. Cities 36:200-209. https://doi.org/10.1016/j.cities.2013.08.004

Kovács Z, Herfert G (2012) Development pathways of large housing estates in post-socialist cities: an international comparison. Housing Stud 27(3):324-342. https://doi.org/10.1080/02673037. 2012.651105

Kovács Z, Herpai T (2011) A panelprogram társadalmi és környezeti hatásai Szegeden. In: Szabó V, Fazekas I (eds) Környezettudatos energiatermelés és -felhasználás. MTA DAB Megújuló Energetikai Munka-bizottsága, Debrecen, pp 322-328

Kovács Z, Tosics I (2014) Urban Sprawl on the Danube. Confronting suburbanization. Wiley Ltd. https://doi.org/10.1002/9781118295861.ch2

Pieniążek M (2010) The peripheral housing estate as a form of urban spatial development: the status quo and perspectives. Miscellanea Geographica 14:273-281

Preisich G (1998) Budapest városépítésének története 1945-1990. Müszaki Könyvkiadó, Budapest

Rietdorf W (1997) Weiter wohnen in der Platte: Probleme der Weiterentwicklung großer Neubaugebiete in den neuen Bundesländern. Institut für Regionalentwicklung und Strukturplanung. Ed. Sigma, Berlin

Rietdorf W, Liebmann H, Knorr-Siedow T (1994) Großsiedlungen in Mittel- und Osteuropa. Regio, Beiträge des IRS 4, Berlin 
Sailer-Fliege U (1997) Transformation of housing markets in East Central Europe. In: Kovács Z, Wiessner R (eds) Prozesse und Perspektiven der Stadtentwicklung in Ostmitteleuropa. Münchener Geographische Hefte 76 Geographisches Institut der Technischen Universität München, L.I.S. Verlag. Passau, pp 33-47

Sillince J (1985) The housing market of the Budapest urban region 1949-1983. Urban Stud 22(2): 141-149

Szelényi I, Konrád G (1969) Az új lakótelepek szociológiai problémái. Akadémiai Kiadó, Budapest

Sýkora L (2009) Post-socialist cities. In: Kitchin R, Thrift N (eds) International encyclopedia of human geography. Elsevier, Oxford

van Kempen R, Dekker K, Hall S, Tosics I (2005) Restructuring large housing estates in Europerestructuring and resistance inside the welfare industry. Policy Press, University of Bristol, Bristol

Open Access This chapter is licensed under the terms of the Creative Commons Attribution 4.0 International License (http://creativecommons.org/licenses/by/4.0/), which permits use, sharing, adaptation, distribution and reproduction in any medium or format, as long as you give appropriate credit to the original author(s) and the source, provide a link to the Creative Commons license and indicate if changes were made.

The images or other third party material in this chapter are included in the chapter's Creative Commons license, unless indicated otherwise in a credit line to the material. If material is not included in the chapter's Creative Commons license and your intended use is not permitted by statutory regulation or exceeds the permitted use, you will need to obtain permission directly from the copyright holder. 